КРИМИНОЛОГИЯ

UDC 343.9

\title{
M.Antinucci
}

\section{THE NEW PUBLIC PROCUREMENT CODE WITHIN INTERNATIONAL RELATIONS AND ANTI-CORRUPTION POLICIES ${ }^{1}$}

This article is the result of the intervention of the delegation of the Sapienza University of Rome to the Italo-Russian Workshop "State and citizens: internal reforms and perspectives for international cooperation" at St. Petersburg International Legal Forum, in St. Petersburg 19-21 may 201; the point is to work for the international cooperation to fight against corruption in public procurement and in general in the public administration. The question of the contrast to the international corruption has already been the subject of extensive debate two years ago during the round table and scientific Italian- Russian seminar "Internalization of business and prevention of financial crimes" [1]. Refs 15.

Keywords: international cooperation, international relations, public procuremant, anti-corruption policies.

\section{Introduction}

The corruption issue in the public procurement is a very old problem of the public sector and, in particular, of the public administrations worldwide. In fact, since the public administrators spend money that do not belong to them there has always been a severe difficulty to reach the value for money and corruption episodes spread all over.

Such awareness received an important recognition also within the United Nations Convention against Corruption (UNCAC) of 2003, which, within the art.9, provided a framework for shaping national public procurement legislation in order to contain the corruption phenomenons.

Following the UNCAC in 2013 the United nations office on Drugs and Crime issued a Guidebook on anti-corruption in public procurement and the management of public finances, that spoke again about transparency, competition and objective criteria in decision-making, that are effective, inter alia, in preventing corruption within the public procurement procedures.

In the European "house" Public procurement has been the subject of the Special chapter in the first EU Anti-Corruption report, published on 3 February 2014. In fact, the convinction that clear, simple public procurement rules, and transparent procedures, be-

Mario Antinucci - criminal lawyer in Rome and prof. of criminal procedure at School of specialization for Legal Professions, Department of Legal, Philosophical and Economics Studies, Sapienza University of Rome; P.le Aldo Moro n. 5, 00185 Roma; e-mail: mario.antinucci1@uniroma1.it

1 This article is a modified version of the paper presented with Sapienza University delegation at St.Petersburg International Legal Forum, in St. Petersburg 19-21 may 2016

(c) Санкт-Петербургский государственный университет, 2017 
sides the main aim of opening the market, contribute to preventing corruption, detecting corruption and redressing corruption, is the fil rouge of the new european directives on public procurement and concessions.

In such context, Italy aligned out the public procurement normative by issuing the legislative decree n. 50/2016 which completely abrogates the previous laws and regulation relating to public procurement and that is mainly focused on:specific measures that prevent corruption, wide transparency within the procedures single phases, competition, innovation and more specific rules related to the selection of the contractors.

Indeed, Italy in application of the obligations assumed within the UNCAC established the National Autority for the Anticorruption (ANAC) that became the main figure in the public procurement handling. The National Anticorruption Plan (P.N.A.) is another efficient instrument in force in Italy that obliges all administration to issue e three years plan related to the anticorruption strategies and measures and that arealigned to the national and international strategies in the sector. There are lot of such instruments and actually Italy has also an Antimafia Code of laws that get more effective the general anticorruption framework.

Coming back to the new public procurement law (PPL), as mentioned, besides the central role confirmed to ANAC, there are specific rules that guarantee the full transparency, competitiveness and clear criteria for the selection of the contactors.

\section{The new Public Procurement Code: from the formality of the procedure to the competence of the entities}

The new Legislative Decree April 18, 2016, n. 50 entered into force on 20 April 2016 on the Code of public contracts and concessions; the Government with an intent certainly meritorious strengthened and partly introduced for the first time new institutions aimed at the protection of constitutional values of competitiveness and efficiency.

In this context in a perspective so to speak bipartisan the new text demands that are to be regarded not only traders but also the contracting authorities.

Incidentally the qualification of contracting unlike the username economic operators qualification is not specifically required by Community Directives in respect of custody procedure nor has ever been disciplined in the national system

The big news of the reform lies in the fact that these requirements are now also required to contracting; The big news of the reform lies in the fact that these requirements are now also required to contracting; in other words as well as the economic operator must prove the requirements to participate in procurement procedures (see. Articles. 83 and 84 of Legislative Decree n. 50/2016) also to the contracting authority must prove Anticorruption National Authority meet the requirements to be able to entrust a job order.

With a clear operational rule: from the date of entry into force of the new qualification of the contracting system ANAC does not release the identification code (IGC) to contracting that proceed to the acquisition of non-covered goods and services or works in achieved qualification (cfr. art. 38, section 9 of Legislative Decree. n. 50/2016).

Closes in other words a circle in the context of a broader strategic plan, namely to reduce contracting by centralizing the commission consequently ensure the professionalization of the same through a system of management and control of their work and ul- 
timately ensuring the same proper exercise of administrative discretion, so much invoked by Community Directives n. 2014/23 / EU, 2014/24 / EU and 2014/25 / EU.

In terms of qualification of economic operators does not change in any cao, at least in ordinary areas, the traditional dichotomy between public works contracts on the one hand for which remains in force the system of SOA certifications (see. art.84, Legislative Decree. n. 50/2016), and other services and supplies (cfr. art.83, Legislative Decree. n. 50/2016) for which the contracting authority may require in relation to the single count individual requirements (eligibility professional, econoico-financial and technical-organizational) capacity among those laid down in legislation, by selecting them and graduandoli depending on the nature and characteristics of the contract they intend to confer (in which case it is necessary to rely more specifically also on Annex XVII of Legislative Decree n.50/2016, entitled "Means of evidence of selection criteria").

Regarding the qualification of public works, the SOA gaming system resists but is partially modified with the provision of such sample testing by the contracting authorities of the possession of the individual requirements that allowed the issue of the certificate (cfr. art. 84, paragraph 6 of Legislative Decree. n. 50/2016).

On the other hand in terms of qualification of public works relies ANAC so the task of making an extraordinary recognition egarding the qualification of public works, the SOA gaming system resists but is partially modified with the provision of such sample testing by the contracting authorities of the possession of the individual requirements that allowed the issue of the certificate (cfr. art. 84, paragraph 6, of Legislative Decree n. 50/2016).

In terms of qualification of public works relies ANAC so the task of making an extraordinary recognition of meeting the operational requirements of by the entities currently operating in the field of certification, how to identify forms of public participation algi themselves and to its certification activities (cfr. art.84, paragraph 3 of Legislative Decree no. 50/2016).

Instead it will be the Minister of infrastructure and transport of ANAC proposal after hearing the competent parliamentary committees to identify within one year of the entry into force of the qualification mode code also alternative or experimental by contracting considered particularly qualified, if necessary through a gradual overcoming of the unique system of qualification of executors of public works (cfr. art. 84, paragraph 12 of Legislative Decree n. 50 /2016).

In terms of services and supplies, the Code rather faithfully transposes the Community Dirtettive. Nonetheless the introduction of two new requirements for economic and financial capacity, such as the relationship between assets and liabilities, can be deduced from the annual accounts (cfr. art. 84, paragraph 4, letter. B, Legislative Decree. n. 50/2016) and the level of insurance cover against occupational risks (cfr. art. 84, paragraph 4, letter. c, Decree. n. 50/16). Among the evidence of the possession of such requirements they resist in any case the appropriate bank references and certificates through budgets (listed in Annex XVII of the Code).

In general with regard to the username traders qualification requirements, both with reference to the work as to the services and supplies they are introduced reputational criteria that will attach importance to the reduction of costs and time in the execution of the order, as well as the litigation rate of companies; the same ANAC will also cure the management and issue the certificate as to business rating (cf. art. 83, paragraph 10 of Legislative Decree n. 50/2016). 


\section{The anti-corruption organization model and the role of specialized training in business environment}

In this context, the regulations introduced by Legislative Decree 8 June 2001, no. 231 are at the forefront compared to other countries. This Decree provides for rules governing the exclusion of companies' administrative liability for crimes committed by executives and / or by employees if the company has adopted and implemented a managing and control model suitable to prevent such offenses, before the criminal offense itself has been committed.

The Italian law takes a punitive approach, consistent with international law standards aimed at sanctioning the proceeds of corruption by confiscation. Such a stance can be established from Legislative Decree 8 June 2001, no. 231, which introduces confiscation by equivalent as main and mandatory sanction. In accordance with this Decree, the confiscation clearly constitutes a punitive instrument, as it may affect properties without any direct correlation to the offense. This results in a paradox whereby a person liable of security measures is instead subject to a criminal penalty.

I listened, among others, to the wonderful report by Attorney-General of the Court of Auditors Couns. Patroni Griffi that struck me for its comprehensiveness and balance, especially with regards to the topic of effectiveness of controls, at the forefront in the sector regulations introduced by the well-known Law 6 November 2012, no. 190 so-called anti-corruption and subsequent amendments. Nevertheless, let us not forget, to name a few examples, that in Italy two witnesses are required in order to release an id card. If I go to Equitalia in order to reduce or schedule installments for a debt, the entity still asks for a photocopy of my id card before proceeding, despite already possessing executive ownership on my legal position and all my data.

It follows that any investigative instrument used in crime policies for prevention of national and international corruption has to "deal with" the internal structure of public administrations, sector laws, and best practices for administrations at every level-center and periphery, local administrations and so on.

As mentioned above, the regulations from articles 6 and 7 of Legislative Decree 8 June 2001, no. 231, clearly require the implementation of anti-corruption organization models, whose effectiveness is related to appropriate education of personnel at every company levels. In accordance with this educational and European framework, the Sapienza University of Rome and ANCE signed a Memorandum of Understanding on July 2014 for offering specialized training to entrepreneurs both on the fight against corruption and on national and international sector regulations.

On the topic of corruption and culture of legality, one of the main cruxes is the issue of professional training for professionals of criminal law. It has to be noted that the recent reform to the Code of Criminal Procedure about remand introduced by article 8 of Law 11 August 114, no. 117, amending article 575, paragraph 2, bis of the Code of Criminal Procedure, lowered to three years the cap prescribed by law for remand in custody. This takes effect immediately for corruption crimes introduced after the amendment to the Law 6 November 2012, no. 190.

On a European level, the change in the roles of the parties involved in criminal trials may be shown in the new professional requirements for defense attorneys. Transnational 
crimes require new up-to-date defensive techniques, such as the European Investigation Order and the investigative circulation in the European legal area.

The Legislative Decree 4 March 2014, no. 32 implements the provisions of Directive 2010/64/EU of the European Parliament and the Council of 20 October 2010, on the right to interpretation and translation of criminal proceedings, according to the authority granted to the Government with Law 6 August 2013, no.96. (Delegation to the Government for the transposition of European Directives and the implementation of other Acts of the European Union - so-called European delegation Law 2013). The transposition of this Directive is further strengthening the procedural safeguards of suspected and accused persons, in accordance with the so-called 2009 Stockholm roadmap. This programme advances legal cooperation between Member States and mutual recognition of judgments in criminal matters having a supranational dimension. Tellingly, it is written in Directive 2010/64/EU, in the preamble, at point (19), second sentence, that: "Suspected or accused persons should be able, inter alia, to explain their version of the events to their legal counsel, point out any statements with which they disagree and make their legal counsel aware of any facts that should be put forward in their defence." This implies the exact understanding by the concerned person of all documents pertaining to the investigation.

According to the Community legislature, clarified by a maximum harmonization Directive, these procedural safeguards should be fully effective even in removing any language barrier from European citizens. Thus, article 4 of the Directive establishes that "irrespective of the outcome of the proceedings", Member States shall be bearing the costs of interpretation and translation and that such obligations shall be carried out "within a reasonable period of time". Pursuant to article 7, the States shall take note through verbalization if the concerned person: a) has been subject of questioning or hearings with the assistance of an interpreter; b) has received a verbal translation or a verbal summary of key documents; c) has waived the right to translation of documents.

\section{Corruption and the Confiscation by Equivalent of Profit Against the Entity}

Starting with the United Nations Convention of Merida on 31 October $2003^{2}$, the supranational approach against corruption has radically changed. This is evident from the recent law amendment of 3 July 2014, no. 99 "Ratification and implementation of the Agreement between the Government of the Italian Republic and the Government of the United States of America on enhancing cooperation in preventing and combating serious criminal offenses".

The confiscation model concerning corruption established by international instruments (UN, UNDOC ${ }^{3}$ ) and by EU regulations advices for the removal of any good or benefit even if only indirectly related to the consummation of the crime, as long as it is susceptible to economic valuation. The derivation requirement is maintained even if the proceeds of corruption are no more recognizable by becoming blended with the assets of the felon or by being transformed into goods of a different kind.

\footnotetext{
${ }^{2}$ Cf. Council Decision 2008/801/EC, of 25 September 2008, concerning the conclusion of the UN Convention against Corruption, on behalf of the European Community [Official Journal L 287 of 29.10.2008].

3 United Nations Office on Drug and Crime based in Vienna.
} 
Recent rulings by the Joint Divisions of the Criminal Court ${ }^{4}$ have underscored the importance of this stance concerning confiscation and tax offenses [2, p. 234]. They have stated in an authoritative interpretation that: "Precautionary seizure aimed at sequestration by equivalent is not permissible against a legal person when no profits of tax offenses directly committed by the legal person itself have been found, with the exception of dummy corporations"

More specifically, the Court of Cassation made a landmark ruling in 2008 establishing the criteria for assessing the profits of crimes, pursuant to Art. 19 of Legislative Decree 8 June 2001, no. 231, by stating that: "The profit of the offense in precautionary seizures aimed at sequestration against a collective entity, pursuant to Articles 19 and 53 of Legislative Decree no.231/2001, is considered as the economic benefit of direct and immediate causal derivation from the crime and it is determined excluding actual benefits obtained by the damaged in the bilateral relationship with the entity"s.

With a landmark ruling ${ }^{6}$, the Court of Cassation has stated the following principle of law: "The receiver manages the assets in accordance with creditor's rights. He represents interests classifiable as rights of bona fide third parties on seized assets. In order to protect these rights on the insolvency estate, it should be given to the receiver the option of acting judicially - both in the procedure regarding confiscation of assets and in the related precautionary seizure. If this possibility could not be made available, such rights would be unreasonably excluded from the protection generally granted, pursuant to article 19 of Legislative Decree no. 231 2001, to rights acquired by bona fide third parties, which would clearly contrast with constitutional principles"

The quoted ruling suggests a theory of counterlimits to confiscation of price and profits of crime [2] against a collective entity prosecuted pursuant to Legislative Decree 8 June 2001, no. 231 [3, p. 1486].

Specifically, the dictum outlines an operating guidebook connected to the interpretation of article 19 of Legislative Decree, no. 231 20013, despite this being specific to bankrupt companies [4].

The greatest driver of transnational organized crime is economic profit. Therefore, relevant authorities should be able to track, freeze, manage and confiscate proceeds from crime. Nevertheless, prevention and effective fight against organized crime should be achieved by neutralizing proceeds from crime and thus be extended, in certain cases, to any asset deriving from criminal activities.

Against this background, on 25 February 2014, the European Parliament voted a directive ${ }^{8}$ according the the ordinary legislative procedure of examination and approval of the proposal of the European Commission (amended by the EU Council). In this direc-

${ }^{4}$ Court of Cassation - Joint Chambers, 30 January 2014, Gubert, with note from Vitale, Le Sezioni unite sulla confisca per equivalente. Reati tributari e 231: una questione ancora irrisolta, in Oss. Archivio Penale 2014.

${ }^{5}$ Court of Cassation - Joint Chambers, 27 March 2008, n. 26654, Impregilo, in Le Società, 2009, p. 351

${ }^{6}$ Court of Cassation, Division 5, 5 December 2013, Patroni Griffi, with note by Ranaldi, Processo de societate, confisca del prezzo o del profitto del reato e teoria dei contolimiti: i compiti del curatore fallimentare, in Arch. Pen., 2014, 1, p. 295.

${ }^{7}$ European Parliament legislative resolution of 25 February 2014 on the directive proposal of European Parliament and Council regarding freezing and confiscation of proceeds from crime in the European Union.

${ }^{8}$ Directive 2014/42/EU of European Parliament and Council of 3 April 2014 concerning freezing and confiscation of capital goods and proceeds from crime in the European Union, in OJ, 29.04.2014, L 127/39. 
tive, confiscation is connected to a criminal conviction, even in absentia. Furthermore, it provides for confiscation in cases where assets are disproportionate to the income, the confiscation of assets transfered to front men, the management of assets by specialized national authorities, the destination to social use of property, without prejudice to procedures of individual Member States. The current European legal framework on freezing, seizure and confiscation of properties is composed by Join Action 98/699/JHA ${ }^{9}$, by Framework Decision 2001/500/JHA of the Council ${ }^{10}$, by Framework Decision 2003/577/ JHA of the Council ${ }^{11}$, by Framework Decision 2005/212/JHA of the Council ${ }^{12}$ and by Framework Decision 2006/783/JHA of the Council ${ }^{13}$.

The implementation reports of the Commission regarding Framework Decisions 2003/577/JHA, 2005/212/JHA and 2006/783/JHA acknowledge that current mutual regimes of confiscation and recognition of freezing and confiscation measures are not fully effective. As the confiscation is hindered by differences between the legal systems of the Member States, this Directive aims to amend and expand the provisions of Framework Decisions 2001/500/JHA and 2005/212/JHA (article 14).

According to the European legislator, in order to effectively contrast transnational crime groups, there may be situations where it is required during investigation that the criminal conviction is followed not only by confiscation of assets associated with a given crime, but also with assets established as proceeds from other crimes.

On a European level, this approach is defined as "extended confiscation". Framework Decision 2005/212/JHA provides for three sets of minimum requirements that may be chosen by Member States in order to implement this type of action.

Subsequently, different Member States have chosen different options when transposing this Framework Agreement, thus deriving different views on extended confiscation in national jurisdictions. Such differences hinder proper cross-border cooperation on confiscation cases. Out of the need for further harmonizing the provisions concerning extended confiscation, a single set of minimum regulations has been defined by Directive 2014/42/ EU of the European Parliament and Council of 3 April 2014 regarding freezing and confiscation of capital assets and proceeds from crime in the European Union [5].

The precondition is that following a final conviction for a criminal offense, it should be possible to confiscate capital assets and proceeds from crime, or assets whose value corresponds to such capital assets or proceeds. In order to contrast economic-financial transnational crime, the final conviction can be in absentia (article 4, paragraph 1) ${ }^{14}$ pur-

${ }^{9}$ Joint Action 98/699/JHA of 3 December 1998 on money laundering and the identification, tracing, freezing, seizing and confiscation of the instrumentalities and the proceeds from crime adopted by the Council on the basis of Article K. 3 of the Treaty on European Union (OJ L 333 of 9.12.1998, p. 1)

${ }^{10}$ Framework Decision 2001/500/JHA of the Council, of 26 June 2001, concerning money laundering and the identification, tracing, freezing or seizing and confiscation of the instrumentalities and the proceeds from crime (OJ L 182 of 5.7.2001, p. 1).

${ }^{11}$ Framework Decision 2003/577/JHA of the Council, of 22 July 2003, concerning the execution in the European Union of orders freezing property or evidence (OJ L 196 of 2.8.2003, p. 45).

${ }^{12}$ Framework Decision 2005/212/JHA of the Council, of 24 February 2005, concerning the confiscation of assets, instruments and proceeds of crime (OJ L 68 of 15.3.2005, p. 49).

${ }^{13}$ Framework Decision 2006/783/JHA of the Council, of 6 October 2006, concerning the execution of the principle of mutual recognition of decisions in confiscation (OJ L 328 of 24.11.2006, p.59).

${ }^{14}$ Cf. Law 28 April 2014, no. 67, Delegations to the Government concerning custodial sentences not entailing imprisonment and reform of sanction system. Provisions on suspension of prosecution with probation and against untraceable persons, in OJ no. 100 of 2 May 2014. 
suant to amended article 420 bis of Code of Criminal Procedure, entitled "absence of the accused person".

If it may not be possible to confiscate capital assets and proceeds from crime on the basis of a final conviction, it may still be carried out in some circumstances, such in the event of illness or flight from prosecution or sentencing. Nevertheless, in case of illness of flight, the existence of a default procedure in Member States should suffice for fulfilling this requirement (article 4, paragraph 2).

In the event of flight of the suspected or convicted person, Member States should implement any reasonable measure and may summon the person for the confiscation procedure or for informing him about it.

It is well known that Italy has significantly delayed the transposition of some important regulatory instruments of the European Union on the subject.

Specifically, the Framework Decision 2006/783/JHA of 6 October 2006, regarding the implementation of the principle of mutual recognition to confiscation orders, is yet to implemented in the Italian legal system ${ }^{15}$. The procedural regulation aims at such mutual recognition by a direct relationship between judicial authorities. The provided deadline for its transposition is expired since more than five years (24 November 2008) ${ }^{16}$.

Even more delayed is the implementation of Framework Resolution 2003/577/JHA of 22 July 2003, on the execution in the European Union of orders freezing property or evidence $^{17}$, whose deadline was 2 August 2005. Such instrument establishes regulations in accordance to with a Member State acknowledges and carries out in its territory a freezing or seizing order issued by the judicial authority of another Member State ${ }^{18}$.

Considering the international legal framework, the so-called extended confiscation should be enhanced and streamlined also in the European legislation. Especially since, given the increasingly aggressive stance adopted by Italian authorities on punitive actions (such as confiscation) and the transnational nature of crime organizations, it can be detected a general trend to delocalize criminal assets in order to protect them by such prevention measures. This trend is increased when appropriate mechanisms of investigative cooperation and judicial assistance are not being employed in the European scenario [6, p. 1169].

On this subject, a topic being currently debated domestically is the irrelevance of undeclared incomes regarding the proof of lawful origin of seized or confiscated assets. Diverging interpretations of article 24 of Legislative Decree 6 September 2011, no. 159 (socalled Anti-mafia Code) entitled "Confiscation", led to a ruling of 12 December 2013 of Joint Chambers, with hearing on 24 May 2014: "If while assessing the disproportion, the

15 OJEU L 328 of 24.11.2006, p. 59.

16 Article 50 of Law 7 July 2009, no. 88 entitled "Provisions for obligations deriving from Italy's membership to the European Communities (Community Law 2008)" granted authority to the Government for implementing a legislative decree containing the regulations required by the aforementioned Framework Decision. This Delegation expired on 7 December 2010 without being exercised. During the 17th Legislature, a draft bill has been presented on 21 March 2013, entitled "Delegation to the Government for transposing Framework Decision 2006/783/JHA of the Council, of 6 October 2006, regarding the implementation of the principle of mutual recognition to confiscation orders".

17 OJEU L 196 of 2.8.2003, p. 45.

18 Article 30 of Law 25 February 2008, no. 34 entitled "Provisions for obligations deriving from Italy's membership to the European Communities (Community Law 2007)" granted authority to the Government for implementing a legislative decree containing the regulations required by the aforementioned Framework Decision. This Delegation expired on 21 March 2009 without being exercised. 
proceeds of fraudulent tax evasion and other unlawful activities are not considered". With a decision handed down on 29 July $2014^{19}$, the Court of Cassation excluded that the recipient of the confiscation measure may appeal to income undeclared to tax authorities in order to justify assets that are disproportionate in value.

Returning to the subject of corruption, the efforts of the European legislator have focused on defining the target of this punitive measure, albeit rather on general terms. Particularly, it is significant the choice of clarifying the concept of profit by highlighting the intention to expand the expropriation boundary beyond the net profit of the crime. On the other hand, none of the preceding definitions establishes clearly the extension of the proceeds from crime, with all the consequences pertaining to the legal positions of third parties not involved in the crime [6, p. 1169].

A simple example may clarify the issue. Let us consider the case of an entrepreneur corrupting a civil servant in order to be awarded a tendered contract and that subsequently carries it out, thus receiving the remuneration predetermined in the tender.

Let us now consider that this tender had as its object a service of high value to be rendered (e.g. the supply of a good or the execution of a work) that only few contractors could actually perform and whose demand in the market would be rather limited.

Let us suppose then that this entrepreneur, on the strength of this tendered contract awarded by corruptive agreement, was able to expel many potential competitors from the reference market thanks to the decrease in demand, leading him to a dominant position and thus to be awarded further contracts. At this point, it is worthwhile wondering what should be confiscated as proceeds from corruption, once the crime is established [7, p. 189]. Should assets equivalent to the value of tender be seized, disregarding the value of the service actually performed for the public administration, or should they be limited to what was effectively "earned" by the entrepreneur? And should the competitive advantage obtained as a result of the tender be considered as "proceeds" from the crime and should it then be calculated for confiscation purposes?

It is evident that the solution chosen in answering such questions can significantly affect the outcome of the punitive action for the physical or legal person involved in the offense and it could even lead to "collateral damages" not conducive to its punitive aims.

For instance, it is very interesting to consider - given its current importance - the recent ruling of the Court of Cassation on the "Ilva Case" 20 on criminal liability of the entity for environmental damage and precautionary seizure of profit pursuant Legislative Decree 8 June 2001, no.231. Building on the Joint Chambers ruling on the "Impregilo" case, the Supreme Court ruled that "in order to establish the profit as originating from expenditure savings, it should be identified a positive economic result effectively determined by the contested offenses". In the present case, according to the Court of Cassation, environmental damages - caused by unlawful expenditure savings originating by omitting remediation works - do not constitute proceeds from crime.

${ }^{19}$ Court of Cassation, Joint Chamber, 29 May 2014 (filed 29 July 2014), no. 33451, President Judge Santacroce, Judge Rapporteur Zampetti, Defendant Repaci.

${ }^{20}$ Court of Cassation - Division 6, 24 January 2014, Ilva S. p.a, in CED 345612 

in idem legal principle

The evolution of the international anti-corruption drive and of the so-called Best Practices aimed at the private sector, currently at the forefront of different political agendas of States and international organizations, created the risk that a company working in different Countries might be prosecuted in those Countries for the same corruption offense. This may be caused even as a byproduct of cooperation and information exchange in criminal law. This possibility is an effect of market globalization and renders prevention of paramount importance at company level ${ }^{21}$.

What is the territorial boundary for applying liability to crimes pursuant to the regulations introduced by Legislative Decree 8 June 2001, no. 231?

Article 4, entitled "Offenses committed abroad", establishes that entities having their registered offices in Italy are also liable to prosecution for offenses committed abroad in the cases and under the conditions provided for by articles 7-10 of the Criminal Law Code, provided that they are not being prosecuted by the State in which such offenses were committed.

As for the scope of this provision, any entity incorporated abroad according to its domestic law, but having in Italy its main administration office or business mission, is subject to the Italian law - thus also to Legislative Decree 8 June 2001, no. 231.

This leads to the question of recognizing exempting effects of organization models adopted on the basis of foreign laws by the Italian legal system. Such models may give exemptions if complying with the requirements provided for by Legislative Decree 8 June 2001, no. 231, and if effectively implemented (like in the case, for example, of subsidiaries with registered offices abroad).

Transnational holding groups have some factors that increase their potential dangerousness in terms of economic crime: the geographical dispersion of their activities; increasing range of effectiveness, volume and complexity of business transactions; increased potential effect of criminal activities; marked difficulty in prosecuting criminal acts.

On the other hand, the differences between provisions in different legal systems and the inevitable confrontation with different jurisprudential systems, sanctioning mechanisms and corrective measures renders even harder for companies to adjust their structures to the provisions of Legislative Decree 8 June 2001, n.231. These factors must be taken into account in the models adopted by the companies of holding groups.

Lastly, it should be noted that Law 146 of 2006 [8, p. 3213], ratifying the Convention and Protocols of the United Nations against Transnational Organized Crime, adopted by UN General Assembly on 15 November 200 and on 31 May 2001, provided at article 10 for the liability of entities for some transnational offenses, like for instance mafia syndicates, association for the purpose of unlawful trafficking in narcotic drugs and migrants (articles 416 bis, Criminal Law Code and 73-80 Presidential Decree 309/90).

It may easily happen that for an instance of international corruption, a multinational company that issued financial instruments in the USA may be subject to at least three separate proceedings: in its country, in the country where the corruption has taken place and in the United States.

\footnotetext{
${ }^{21}$ Report of the Flick Committee to the Board of Directors of Finmeccanica Spa of 31 March 2014.
} 
Furthermore, given the increasing complexity of trade, financial operations, tenders and international investments, it is more and more likely that different professional subjects (brokers, agents, trustees, etc.) from different countries may be involved. Each one of them may qualify for starting an investigation and prosecuting offenses, thus clearly creating a conflict of jurisdiction whose effects may impact the implementation of the criminal law principle called ne bis in idem, e.g. when validating arrests in active or passive extradition or when executing the EAW (European Arrest Warrant) [9, p. 577].

In this regard, it is discussed in the literature [10, p. 208] the worrying and widespread phenomenon of so-called carbon copy prosecution, that is actions undertaken for the same events after the conclusion of the action that led to the discovery of corruption (like a ruling or a transaction), in other States who can claim jurisdiction in the matter. In other words, the authorities of the State where the offense has taken place, after hearing of the sentence or of the admission of liability in the proceedings before the authorities of the first State, undertake the same action, making any kind of defense impossible for the defendant, which is also exposed to civil and administrative actions from Government Agencies and independent Authorities for the same offense tried in criminal court.

The topic is still ongoing and it was the subject of a recent decision of the ECtHR in the case Grande Stevens and others v. Italia of 14 March 2014, with whom it has been annulled Italy's reservation to article 4 of Protocol no. 7 of the ECHR, thus ruling against Italy for violating the principle of ne bis in idem, established by that provision and by the right to a fair trial pursuant to article $6, \S 1$ of the ECHR. In the present case, it was about a heap of administrative and financial sanctions (in addition to the prohibition to assume positions of administration, management and control of listed companies) imposed by the Italian Securities and Exchange Commission and a conviction in a criminal proceedings $\mathrm{s}^{22}$.

Therefore, the protection and the correlated procedural safeguards for the suspected person can be found in the constitutional provisions of the countries involved in the legal proceeding, but often the principle of ne bis in idem is not acknowledged with respect to pending proceedings in different States.

For instance, in the United States it is possible an overlap of federal and state actions (it is termed as "dual sovereignty") [11, p.769] and thus the conviction for the same offense in a foreign country is even less relevant.

In the EU, the the principle of ne bis in idem, besides being explicitly recognized in many Constitutions of its Member States, is a fundamental principle with legislative force established in the Convention implementing the Schengen Agreement ${ }^{23}$, in article 50 of Charter of Fundamental Rights ${ }^{24}$, integrated in primary legislation by Article 6 the EU Treaty as amended by the Lisbon Treaty of December 2009, beside in a number of legal acts of EU Institutions ${ }^{25}$.

${ }^{22}$ Cf. Report of the Office for Abstracts of the Court of Cassation of 8 May 2014, "Considerazioni sul principio del ne bis in idem nella recente giurisprudenza europea: la sentenza 4 marzo 2014, Grande Stevens e altri c. Italia".

${ }^{23}$ Convention implementing the Schengen Agreement of 14 June 1985, between the Governments of the States of the Benelux Economic Union, the Federal Republic of Germany and the French Republic on the gradual abolition of checks at their common borders, in EUOJ, 22 September 200, L. 239/19

${ }^{24}$ Article 50 (right not to be tried or punished twice for the same offense) establishes that: "No one shall be liable to be tried or punished again in criminal proceedings for an offense for which he or she has already been finally acquitted or convicted within the Union in accordance with the law".

${ }^{25}$ Resolution of European Parliament on 22 May 2012 on an EU approach on criminal law (2012/2013), in EUOJ of 13 September 2013, C264 E/7, which acknowledges at article 4 the importance of the principles 
Those are not simple statements of principle, as demonstrated by the creation in 2002 of EUROJUST, with the specific mandate of sustaining and strengthening coordination and cooperation between national authorities on the fight against forms of serious transnational crimes concerning the European Union ${ }^{26}$.

Particularly, it aims at preventing conflicts of jurisdiction, determining which authority "may be in a better position to undertake an investigation or to prosecute specific acts" 27.

Considering the most frequently involved countries, however, it holds true that in most cases the defense on the basis of constitutional principles remains a weak solution on the effectiveness of the rights of defense and the rules of a fair trial. Hence, the need for strengthening international coordination, both on investigation instruments and regulations of criminal proceedings.

This is the general context in which originates the proposal of a new European Prosecutor $^{28}[12$, p. $149 ; 13$, p. 168$]$ with the task of identifying and prosecuting in the national tribunals the perpetrators of crimes against the EU budget.

The EU already has an Anti-fraud Office, the OLAF. Once the European Prosecutor is established, the OLAF will be no more responsible for administrative investigations in cases of fraud against the Union or further crimes against the EU financial interests, but it will still be investigating on other irregularities, such as offenses committed by EU personnel without financial impact [14, p.290].

With recent Directive 2014/41/EU of 3 April 2014 (in EUOJ, 1 May 2014, L 130/1) on the European Investigation Order (EIO) in criminal matters, the European Institutions have established an instrument with a new and diverse potential since, building on the principle of mutual recognition, it is the product of "a new approach" willing to set up a "a comprehensive system for obtaining evidence in cases with a cross-border dimension", thus substituting "all the instruments already existing in this sector" and able to be used for "any kind of evidence" with precise and quick execution modalities and limited reasons for refusal (point no. 6).

The innovation from precedent instruments consists of the provision according to which an investigated or accused person or a defense counsel may request an EIO, consistently with the applicable rights of defense in accordance with national law and criminal procedure (article 1, paragraph 3) [15, p.323].

\section{CONCLUSION}

This subject, whence the name of today's conference originates from, must be addressed with courage and intellectual integrity by all of us, the different parts of the civil society, the public institutions, the entrepreneurs and the legal professionals, the youth and the new generations.

governing criminal law, such as "the principle of ne bis in idem: which means that a person who has been convicted or acquitted by a final judgment in one Member State cannot be prosecuted or punished for the same matter in criminal proceedings in another Member State"

${ }^{26}$ Decision of the EU Council 2002/187/JHA of 28 February 2002 which establishes Eurojust in order to strengthen the fight against forms of serious crime, EUOJ of 6 March 2002, L63/1.

27 Article 6 letter (a) of the Decision othe EU Council 2002/187/JHA cited.

28 Bruxelles, 17 July 2013, COM (2013) 532; Alesci, La Procura europea per i reati lesivi d interessi finanziari: la proposta di regolamento tra luci ed ombre, in Arch. pen., 2014, 149; Squillaci, In margine alla proposta di istituzione della Procura europea per la tutela degli interessi finanziari dell'Unione, ibid., 168. 
All the public policies of the European governments share the belief of a direct correlation between the criminal density connected to corruption of States' political and economic protagonists and the lack of availability of investments on young talents, new generations, both in the entrepreneurial and in the professional fields.

In most Member States, anti-corruption policies have gained an increased prominence in government agendas and the financial crisis has drawn attention to the integrity and accountability of policy-makers. Most Member States that are currently in serious financial difficulties have acknowledged the seriousness of issues related to corruption and have created (or are planning) anti-corruption programs in order to deal with the risks deriving from this issue and with the diversion of public funds.

In some Member States, the economic adjustment programs provide for explicit obligations related to anti-corruption policies. Even when not formally connected to adjustment programs, anti-corruption policies complement the adjustment measures, especially in those countries in which corruption is a serious issue. During the European Semester of economic policy coordination, recommendations for efficiently fighting corruption have been laid out.

Among the most vulnerable sectors, urban development and building projects are certainly very exposed to corruption risks and to infiltration of internal and transnational organized crime.

The Romans used to say ubi societas ibi ius. There is no doubt that the hendiadys "corruption and culture of legality", in its correct semantic meaning, sets a problem of knowledge, awareness of the limit, and thus of education, a task entrusted primarily to cultural institutions, of which the Universities, pursuant to art. 33 of the Constitution, represent in our legal system their highest expression. Today this needs to be addressed necessarily on a European and supranational scale in compliance with the European Convention of $\mathrm{Hu}$ man Rights, the EU Treaty of 2009 and the International Covenant on Civil and Political Rights of the UN.

\section{References}

1. Antinucci. Internalization of business and prevention of financial crimes. Reports of international Round Table, 185, Pisa, 2016.

2. Gaito. Premesse conoscitive per l'approfondimento dei problemi della nuova giustizia penale patrimoniale. Available at: www.foroeuropa.it, 13.

3. Gaito, Furfaro. Il procedimento penale amministrativo. Procedura penale. Ed. by Gaito, Milano, 2013, p. 1486.

4. Compagna. Obbligatorietà della confisca di valore e profili di discrezionalità nelleventuale sequestro: il necessario contemperamento degli interessi costituzionali in gioco e l'ipotesi di fallimento. Court of Cassation, 2009, p. 3037.

5. Antinucci. Osservazioni a prima lettura sulla Direttiva 2014/42/UE relativa al congelamento e alla confisca dei beni strumentali e dei proventi da reato nell'Unione europea. Cultura penale e spirito europeo, Arch. Pen., no. 2/14. Available at: www.archiviopenale.it.

6. Gaito, Antinucci. Prescrizione, terzo estraneo e confisca dei beni archeologici (a margine della vicenda dell'Atleta Vittorioso di Lisippo). Bargi, Cisterna (ed.). La giustizia patrimoniale penale. Torino, II, 2011, p. 1199.

7. Pistorelli. La confisca dei proventi della corruzione nelle convenzioni internazionali e nel diritto dell'Unione Europeo. Bonelli - Mantovani (ed.). Corruzione nazionale e internazionale. Milan, 2014, p. 189.

8. Antinucci. Contraddittorio e dosimetria della pena: davvero possibile un'equazione algebrica? Giur. It., 2012, p. 3213.

9. Antinucci. La controversa tutela della libertà dell'estradando. Giur. it., 2013, p. 577. 
10. Serravalle. Corruzione internazionale e "ne bis in diem". Bonelli-Mantovani (ed.). Corruzione nazionale ed internazionale. Milano, 2014, p. 208.

11. Colangelo A. J. Double Jeopardy and Multiple Sovereigns: A Jurisdictional Theory. Washington University Law Review, 2009, p. 769.

12. Alesci. La Procura europea per i reati lesivi d interessi finanziari: la proposta di regolamento tra luci ed ombre. Arch. pen., 2014, p. 149.

13. Squillaci. In margine alla proposta di istituzione della Procura europea per la tutela degli interessi finanziari dell'Unione. Arch. pen., 2014, p. 168.

14. Antinucci. Il procedimento di distruzione delle merci illegali o contraffatte. Pisa, 2014, $290 \mathrm{p}$.

15. Antinucci. Le investigazioni del difensore. Gaito (ed.). Procedura penale. Milan, 2013, 323 p.

For citation: Antinucci M. The new public procurement code within international relations and anticorruption policies. Vestnik SPbSU. Law, 2017, vol. 8, issue 1, pp. 62-75. DOI: 10.21638/11701/spbu14.2017.104.

Received 11.07.2016

Accepted 01.12.2016 